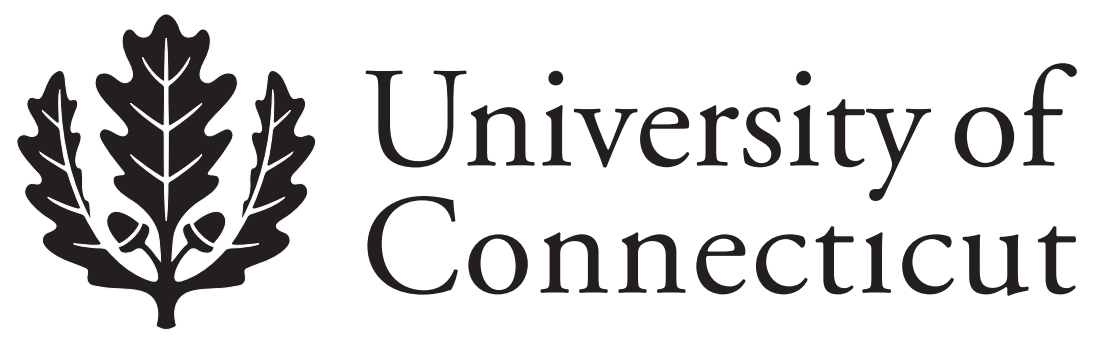

Department of Economics Working Paper Series

\title{
International Money and Finance
}

Paul Hallwood

University of Connecticut

Ronald MacDonald

University of Glasgow

Working Paper 2008-02

January 2008

341 Mansfield Road, Unit 1063

Storrs, CT 06269-1063

Phone: (860) 486-3022

Fax: (860) 486-4463

http://www.econ.uconn.edu/

This working paper is indexed on RePEc, http://repec.org/ 


\begin{abstract}
We discuss the effectiveness of pegged exchange rate regimes from an historical perspective, drawing conclusions for their effectiveness today. Starting with the classical gold standard period, we point out that a succession of pegged regimes have ended in failure; except for the first, which was ended by the outbreak of World War I, all of the others we discuss have been ended by adverse economic developments for which the regimes themselves were partly responsible. Prior to World War II the main problem was a shortage of monetary gold that we argue is implicated as a cause of the Great Depression. After World War II, more particularly from the late-1960s, the main problem has been a surfeit of the main international reserve asset, the US dollar. This has led to generalized inflation in the 1970s and into the 1980s. Today, excessive dollar international base money creation is again a problem that could have serious consequences for world economic stability.
\end{abstract}

Journal of Economic Literature Classification: F31, F33, N20

Keywords: Bretton Woods, exchange rate expectations gold standard, new Bretton Woods, realignment expectations, pegged exchange rates, target zone, world economic instability 


\section{Pegged exchange rates and the world monetary system}

We examine important aspects of pegged exchange rate systems, emphasizing their link to economic recession, inflation and inflation expectations. Since the last quarter of the $19^{\text {th }}$ century there has been a succession of international pegged exchange systems, initially based on gold and sterling, later on the US dollar as the ultimate reserve asset. Production of these assets is an important part of an international monetary system. Shortage of monetary gold, during the inter-war period is heavily implicated as a causal factor in the world depression. "Over-production" of US dollars as central bank reserve assets (that is, as base money) was a cause of accelerating inflation from the late-1960s through the 1970s. In both historical episodes malfunction led to the abandonment of those international monetary systems. Moreover, from the 1990s onwards a new set of countries, especially the emerging markets of China and East Asia, created a new "periphery", pegging to the US dollar and accumulating dollar denominated foreign exchange reserves. This new system has been dubbed the "New Bretton Woods system", in which the US dollar continues to provide the services of store of value, medium of exchange, and numeraire, while the responsibility of the US is not to over-produce dollars - so as to contain inflation, through increasing its net international indebtedness through large and persistent current account deficits. It is the stability of this latter system that is currently in question: fearing devaluation of the dollar, will the new periphery diversify out of dollar reserve assets, and in so doing again bring a bout of instability into the world financial system? 
We examine the performance of over a century's worth of experience with pegged exchange rate systems. We emphasize the credibility of these systems in their different phases, as well as their association with world economic recession and world inflation. It is apparent that no international pegged exchange rate system has worked well for very long, except, perhaps, the classical gold standard which was ended in 1914 by the outbreak of World War I. Even then, US adherence to the system was severely in doubt for about a half decade during the 1890s. The other major international pegged regimes have been ended by development of adverse economic conditions, themselves associated with the operation of the pegged system itself.

\section{Sections}

1. System design (page 4)

2. New Bretton Woods system (page 6)

3. Inflation and the international monetary system (page 8)

4. Pegged exchanges as rate target zones (page 12)

5. Credibility (page 14)

6. Simplest test (page 15)

7. Calculating realignment expectations: drift adjustment method (page 16)

8. Classical and interwar gold standard regimes (page 17)

9. Credibility and capital flows (page 19)

10. Interwar period (page 22)

11. Playing by the rules of the game (page 24)

12. The gold standard and the Great Depression in the USA (page 25)

13. Demise of the gold bloc, 1933-36 (page 27)

14. Calculating devaluation probabilities (page 29)

15. Dirty floating (page 32)

16. Postscript (page 38)

17. Dollar standard in an era of volatile exchange rates (page 40)

18. A currency board system, Argentina, 1991-2002 (page 42)

19. Official dollarization in Latin American: would it work? (page 43).

20. Conclusions (page 45) 


\section{System design}

Institutional structures and practices in pegged exchange rate systems must allow for the simultaneous and policy-consistent solution of national balance of payments, exchange rate structures and relative and absolute levels of national money supplies. Inconsistency implies that at least one member of the system is dissatisfied with the outcome for its balance of payments, or, exchange rate, or, money supply and might take steps to move to a preferred position, so upsetting the international equilibrium. Suppose that $n$ countries, each with its own currency and central bank, form a monetary union by pegging exchange rates between themselves - for example, as in the international gold standard, the Bretton Woods system, and the new Bretton Woods system. In an international monetary system of $n$ countries only $n$ - 1 balance of payments can be independently determined; $n-1$ countries can independently set balance of payments targets (or, what amounts to the same thing, targets for changes in their net international net indebtedness); the $n$th country has to accept the outcome or the system is inconsistent.

For an $n$-country monetary union we can write

$$
S_{1} \Delta F_{1}+S_{2} \Delta F_{2}+\ldots+S_{n-1} \Delta F_{n-1}+\Delta F_{n}=0
$$

where the $\Delta F_{i}$ is the balance of payments of country $i$ measured as the domestic currency value of the change in its foreign exchange reserves; and $\mathrm{S}_{\mathrm{i}}$ is the domestic price of the numeraire currency (usually the US dollar), or of gold (as in the gold standard). In a world of $n$ countries the world's balance of payments sums to zero (as one country's surplus is another's deficit). If 
$n$ - 1 countries each set a target for their balance of payments (by setting both an exchange rate, $S_{i}$, and the domestic currency value of $\Delta F_{i}$ ), for the system to be consistent (to sum to zero) the $n$th country must not try to set an independent target for its balance of payments, $\Delta F_{n}$. Nor must the $n$th country intervene in the foreign exchange market in an effort to set any of the exchange rates $S_{1}, \ldots, S_{n-1}$ that have been chosen by the other members of the system. (It might be tempted to do so if, for example, the $n$th country's government thought that $\Delta F_{n}$ was too large and negative and so tried a devaluation of its currency - i.e. increasing the values of $S_{i}$.) Such a policy is the stuff of competitive devaluations, trade wars and use of foreign exchange controls sure signs that the IMS has become inconsistent.

Equation (1) crystallizes the debate in the late-1960s and early-1970s over the break-up of the Bretton Woods system. One view was that the USA as the $n$th country practiced "benign neglect," leaving $\Delta F_{n}$ to be set as a residual. But the USA, tiring of its large payments deficits, in 1971, set out to devalue the dollar. In doing so it succeeded in breaking up the existing international monetary system because other countries would not accept new values for their exchange rates - initially set in the Smithsonian Agreement (1971). An opposing view - the "European view" - was that the USA independently set a target for the rate of monetary growth and that this determined the change in US foreign exchange reserves. The other members of the system had to accept the consequent increase in their foreign exchange reserves and increases in their domestic money supplies (at least to the extent that sterilization was limited in effect). In other words, at least some of the $n-1$ countries were also dissatisfied with the system and were not interested in prolonging its existence. Some commentators think that China, and some oil 
exporters are in this position, and are ready to 'dump' the dollar, with possible serious implications for the USA; a weakening dollar would be inflationary.

\section{New Bretton Woods system}

Dooley, Folkerts-Landau and Garber (2003) ask if the present international monetary system, with the dollar at its center, stable? The worry is that the US runs large balance of payments deficits, and that many countries are building up massive official (i.e. government held) foreign exchange reserves - buying US federal government bonds. Moreover, citizens of still other countries are buying up large amounts of US private sector assets - stocks, private sector bonds, mortgages, land etc. Can the US therefore continue to sell paper assets to the rest of the world while the rest of the world sells the US real goods and services? Paper-for-goods might eventually be seen as being a bad deal.

The Dooley et al. argument runs as follows. Trade account countries (TAC), such as China and many oil exporters, peg their exchange rates against the dollar at an artificially depreciated level. They do this to stimulate exports to the USA as part of a broader industrialization strategy. In the meantime they run large balance of payments surpluses with the USA and accumulate large foreign exchange reserves in US dollars. US net international indebtedness is sky-rocketing. The original trade account countries, in the 1960s, were mainly in Western Europe (especially Germany), as well as Japan. Once their industrial economies had recovered following WWII, they ended this development strategy, switching to floating their exchange rates in 1973. They became "capital account countries". About twenty years later a new periphery has appeared East Asia, wants to export to the US as part of their own industrialization strategies. 
What of the countries floating against the US dollar (EU, UK, Canada, Australia, Japan, etc.)? These countries are "capital account countries" (KAC) known as such because they have open capital accounts - allowing their citizens to invest abroad. What happened during the 1990s until just a few years ago (its now 2008), was that KAC ran current account surpluses with the US while their private sectors invested in US assets. As their capital outflows just about offset their current account surpluses their currencies remained more or less stable against the dollar.

However, in the last couple of years or so KAC investors have started to worry about dollar weakness and have reduced investment flows to the US. As a result, their currencies have strongly appreciated against the dollar - e.g. the euro has recently moved from about $\$ 1.15$ per euro to over $\$ 1.45$, and it may well go higher. The knock-on effect from this is that KAC lose market share in the US.

But if KACs have reduced their buying of dollars gushing into the world economy through large US balance of payments deficits will anybody step in to buy them? The answer, so far, is "yes". The TACs are only too willing to do so and are glad that their competitors in the KAC region have allowed their exchange rates against the dollar to appreciate. Thus, trade account countries accumulate evermore official dollar exchange reserves.

What if East Asian countries decided that its industrialization strategy based on a weak currency and plenty of exports to the US had run its course - moving to floating, so becoming KACs? Dooley et al. say that South Asia is only too willing to step in as the next group of TACs, so financing US balance of payments deficits. 
But is this international monetary system stable? Certainly risks are accumulating. If China decided not to accumulate any more dollar denominated official foreign exchange reserves switching to some other reserve asset such as the euro, the dollar would almost certainly collapse. The knock on effects of that could include rampant inflation and much higher interest rates in the US.

Indeed, an important question is what is the association between an international system of pegged exchange rates and world inflation?

\section{Inflation and the international monetary system}

Time-inconsistency problems arise when policy-makers have incentives to deviate from announced policy once private decision-makers have adjusted to it (Kydland and Prescott, 1977). A central bank, having announced a policy of low-inflation, may subsequently engineer an inflation-surprise in order to reduce unemployment. If private decision-makers anticipate this, the low-inflation policy is not credible, inflation-expectations will not fall, and the inflation-unemployment trade-off will remain unfavorable. History appears to show that to avoid time-inconsistency a central bank should adopt a commitment-mechanism which credibly makes monetary policy non-discretionary the gold standard appears to be one such.

Another view is that an exchange rate regime can be interpreted in the context of policy rules versus discretion. Giovannini (1993) sees pegged exchange rates as 'natural' - because they provide a credible policy rule that stabilizes inflation expectations more effectively than does, say, monetary targeting. The advantage of pegging is that the policy is overt and everybody knows when the rule has been broken; but monetary targeting is opaque: which monetary aggregate is in play, can it be controlled, when has the target been missed? Pegged international systems have been abandoned in 
the face of serious shocks - such as the Napoleonic Wars, WW1, the Great Depression and the Vietnam War - which have excessively increase the cost of adherence to the regime. On this view floating exchange rates are 'interlude regimes' - a mere 'escape clause' utilized when the going get too tough.

If a pegged exchange rate regime can be classified as a 'policy rule with limited discretion' (because of the existence of a narrow fluctuation band), credibility of commitment becomes an issue: monetary policy may not be consistent with the commitment to the exchange rate peg. If a monetary authority uses its scope 'within the exchange rate band' to accommodate deflationary real shocks it may over do it, causing a devaluation. When discretion is practiced the very commitment to an exchange rate peg may not be deemed time-consistent.

Bordo and Kydland (1992) examine time consistency features of the classical gold standard that operated in the last quarter of the nineteenth century to 1914, finding that adherence by the monetary authorities to the 'rules of the game' constituted a credible commitment not to inflate. They contrast the experience of strong adherents to the classical gold standard with the weakly committed Italy - finding that interest rates on Italian government bonds included a large and variable risk premium - a fact which they explain in terms of inflation expectations not having benefited from a credible monetary policy. ${ }^{1}$ A similar argument about the USA in the 1890s is made by Friedman and Schwartz (1963), Schwartz (1987), and Hallwood, MacDonald and Marsh (1999).

\footnotetext{
1. Furthermore, the implications for time inconsistency of Britain not returning to the gold standard after WW1 were well understood at the time by Sir Otto Niemeyer, a Treasury advisor, who wrote in 1924 that if it was seen that the UK had lost its nerve over a return to the gold standard "the immediate consequence would be a considerable withdrawal of balances and investment (both foreign and British) from London; a heavy drop in Exchange; and to counteract that tendency, a substantial increase in Bank rate" (quoted Moggridge, 1969, page 47).
} 
Alogoskoufis and Smith (1991) examine time series properties of pegged and floating exchange rate regimes for UK and US from the classical gold standard until 1987. They find that inflation rates are a first-order autoregression and they compare $\rho$ values for various historical sub-periods.

In a first order autoregression

$$
\mathrm{x}_{\mathrm{t}}=\rho \mathrm{x}_{\mathrm{t}-1}+\mathrm{v}_{\mathrm{t}}
$$

where $\rho$ is the autoregressive term. lies between plus/minus unity. The closer is $\rho$ to positive unity the greater is the effect of $\mathrm{x}_{\mathrm{t}-1}$ on $\mathrm{x}_{\mathrm{t}}$ - the more 'persistent' is the time series as a shock to $\mathrm{x}_{\mathrm{t}-1}$ more strongly influences $\mathrm{x}_{\mathrm{t}} \ldots \mathrm{x}_{\mathrm{t}+\mathrm{n}}$.

Examination of the first column of table 1, in both the UK and the US, inflation persistence (high $\rho$ values) is greater during periods of floating exchange rates. For example, taking 1967 (when the pound was devalued) as the post-WWII divide between fixed and floating rates, $\rho$ jumps from 0.27 during the 1948-1967 period to 0.74 during 1968-1987. For the US, the respective $\rho$ values are 0.25 and 0.70 . 


\section{Table 1 \\ How current inflation depends on past inflation $\mathbf{p}$, and the expectations augmented Phillips curve $\alpha_{1} \rho$.}

\begin{tabular}{|c|c|c|c|}
\hline$\underline{\mathrm{UK}}$ & $\mathrm{p}$ & $\alpha_{1} \rho$ & Exchange Rate regime \\
\hline$\overline{1.1} 857-1987$ & .76 & 0.95 & \\
\hline 2. $1857-1913$ & .26 & 0.30 & fixed - gold standard \\
\hline 3. 1914-1987 & .74 & 0.91 & fixed and floating \\
\hline \multicolumn{4}{|l|}{ Post WWII } \\
\hline 4. $1948-1987$ & .80 & 0.78 & \multirow{4}{*}{$\begin{array}{l}\text { fixed - Bretton Woods } \\
\text { mainly floating }\end{array}$} \\
\hline 5. 1948-1967 & .27 & 0.28 & \\
\hline 6. 1968-1987 & .74 & 0.46 & \\
\hline$\underline{\mathrm{USA}}$ & & & \\
\hline$\overline{7.1892-1987}$ & .64 & 0.64 & \multirow{4}{*}{$\begin{array}{l}\text { fixed - gold standard } \\
\text { fixed and floating }\end{array}$} \\
\hline 8. 1892-1913 & .20 & -0.17 & \\
\hline 9. 1914-1987 & .63 & 0.63 & \\
\hline Post WWII & & & \\
\hline $10.1948-1987$ & .62 & 0.53 & \multirow{3}{*}{$\begin{array}{l}\text { fixed - Bretton Woods } \\
\text { mainly floating }\end{array}$} \\
\hline 11. 1948-1967 & .25 & 0.23 & \\
\hline 12. $1968-1987$ & .70 & 0.81 & \\
\hline
\end{tabular}

Notes: All $\rho$ and $\alpha_{1} \rho$ values are statistically significant except for $\rho$ numbers 5,8 and 11 , and $\alpha_{1} \rho$ numbers 5 and 8 . Wald tests for the significance of shifts between the crucial periods 2 versus 3, 5 v. 6, 8 v. 9, and 11 v. 12 are statistically significant. Source: Alogoskoufis and Smith (1991).

Alogoskoufis and Smith (1991) also estimate expectations augmented Phillips curves for the different time periods as:

$$
\Delta \mathrm{w}_{\mathrm{t}}=\alpha_{0}+\alpha_{1} \rho \Delta \mathrm{p}_{\mathrm{t}-1}-\alpha_{2} \Delta \mathrm{u}_{\mathrm{t}}-\alpha_{3} \mathrm{u}_{\mathrm{t}-1}+\xi_{\mathrm{t}}
$$

where in $\operatorname{logs} \mathrm{w}_{\mathrm{t}}$ is the nominal wage, $\rho$ the first-order-autoregression coefficient, $\mathrm{p}$ the consumer price index, $\mathrm{u}_{\mathrm{t}}$ the unemployment rate and $\xi_{\mathrm{t}}$ a white noise error term. It is the increase in $\alpha_{1} \rho$ that measures the upward shift in the Phillips curve due to increased inflation expectations. Calculated values of $\alpha_{1} \rho$ are shown in the second column of table 1 .

These findings relate to the loss of credibility of commitment and the time consistency of monetary policy under floating exchange rates. The evidence is that in table $1 \alpha_{1} \rho$ jumps dramatically in 1914 and again in the late-1960s. In other words, wage setters began to give a greater weight to past 
inflation - as a predictor of expected inflation (presumably because they expected the effect of past inflation on the real money supply to be accommodated) - just at the time when pegged exchange rates were abandoned and the prospect for monetary accommodation increased.

\section{Pegged exchange rates as target zones}

In most pegged exchange rate systems a central rate (par value), and a fluctuation band, or, 'zone', for an exchange rate is declared and the monetary authorities commit to manage monetary conditions so as to make the commitment stick. This was the case under the Bretton Woods system 1959-1971, the EMS 1979-1999, and the many arrangements today where emerging markets such as China peg to a foreign currency or to a currency basket. The classical gold standard and the interwar gold standard, 1925-31, for most adherents, were an implicit pegged exchange rate system as currency prices of gold defined central rates and the gold points set the width of fluctuation bands.

Assuming that financial markets believe that the monetary authorities will allow the quantity of money and interest rates to be consistent with the exchange rate, the exchange rate is determined as:

$$
\mathrm{s}_{\mathrm{t}}=\mathrm{m}_{\mathrm{t}}+\mathrm{v}_{\mathrm{t}}+\alpha_{2} \mathrm{E}_{\mathrm{t}}\left[\mathrm{ds}_{\mathrm{t}}\right] / \mathrm{dt}
$$

where, in natural logarithms, $s_{t}$ is the domestic currency price of foreign exchange at time $t, m_{t}$ the money supply (which is an exogenous policy variable), $\alpha_{2}$ is the semi-elasticity of demand for money, $\mathrm{v}_{\mathrm{t}}$ is a 'general purpose' term that includes anything else that impacts the demand or supply for money (e.g. changes in real income). Most simply $\mathrm{v}_{\mathrm{t}}$ is taken to be the cumulative value of velocity (Miller and Weller, 1991). Shocks to velocity are random with zero mean, and normally distributed such that the cumulative value of $v_{t}$ follows a continuous-time random walk. In the original Krugman (1988) model the possibility of realignments, or shifts, of the 
central parity were ignored. Bertola and Caballero (1992) proposed a variant of the Krugman model in which the movement of the exchange rate is in natural logs equal to the sum of the exchange rate within the band, $x_{t}$, and the central parity rate, $c_{t}$ :

$$
s_{t}=x_{t}+c_{t}
$$

Using this expression the expected change in the exchange rate may, in turn, be defined as

$$
E_{t} \frac{d s_{t}}{d t} \equiv E_{t} \frac{d x_{t}}{d t}+E_{t} \frac{d c_{t}}{d t}
$$

Where $E_{t}\left(d x_{t} / d t\right)$ is the expected rate of currency depreciation within the band and $E_{t}\left(d c_{t} / d t\right)$ is the expected rate of realignment. On using this definition of $E_{t}\left(d s_{t} / d t\right)$ in equation (4) and subtracting $c_{t}$ from the resulting expression we obtain an equation describing the exchange rate within the band as:

$$
x_{t}=h_{t}+\alpha_{2} E_{t} \frac{d x_{t}}{d t}
$$

where $h_{t}$ is the new composite fundamental and is equal to $f_{t}-c_{t}+a_{2} E_{t}\left(\mathrm{~d} c_{t} / \mathrm{d} t\right)$.

Equation (7) has an immediate implication for empirical tests of how secure is a given exchange rate peg - do financial markets behave as if it is secure or not. Even if uncovered interest rate parity holds continuously, this extended target zone model suggests that one cannot say a priori what the relationship between the exchange rate and the interest rate differential will be like (in the basic Krugman (1988) model it is supposed to be negative). This is because uncovered interest rate parity holds for the total expected change in the exchange rate which from equation (7) is equal to two elements. One would expect there to be a negative association between the expected rate of currency depreciation within the band and the exchange rate, but one cannot say 
anything about the relationship between the expected rate of alignment and the exchange rate.

Since the latter component of equation (7) is time varying it could easily swamp the former, resulting in a positive or negative relationship between the exchange rate and the interest differential (hence the positive association referred to above may be explained in this way). ${ }^{2}$

\section{Credibility}

A target zone is credible - in the sense that the market believes that the exchange rate will be contained within it - if it is believed that the monetary authorities are committed to managing fundamentals to that end. Thus, to maintain credibility, an exogenous shock to fundamentals, say a fall in real economic activity that would otherwise push the exchange rate outside of the target zone, must be offset by a monetary contraction - for instance, by open market sales of domestic securities. Thus, at the edges of a target zone, monetary policy must be geared exclusively to the exchange rate and not, say, towards influencing business conditions. But when the exchange rate is in the interior of the zone the monetary authorities do have some freedom of action.

How can we tell whether monetary authorities under various pegged exchange rate regimes have behaved in such a way as for financial markets to regard a commitment to a peg (and its fluctuation band) to be credible? $?^{3}$ To answer this question some measure of realignment expectations is needed.

This measure has been developed in Svensson (1991), Svensson (1992) and Bertola and Svensson

\footnotetext{
${ }^{2}$ A key feature of the target zone model is that exchange rates should be mean reverting within the band, and this is stressed by Svensson (1991). Anthony and MacDonald (1998, 1999) test this key property of the target zone model and for the ERM experience they find some evidence in favour of mean reversion (particularly towards the end of the ERM experiment) and also that the size of the band is not curial in determining this finding.

3 Under the gold standard there was no international commitment to a pre-defined target zone. Rather, target zones existed as bi-products of mint par parity and gold-movement transaction costs, the latter of which defined gold export and import points which acted as a fluctuation band.
} 
(1993). A finding of statistically significant realignment expectations suggests that the authority's commitment to a given exchange rate peg is not credible. The market may be interpreted as expecting a devaluation (if monetary policy is deemed to be too loose), or, upvaluation (if too tight).

\section{Simplest test}

This method of calculating realignment expectations utilizes the concept of uncovered interest parity which says that the interest differential between two countries is equal to the expected rate of change of the exchange rate.

In order to bring the following argument together we repeat equation (5): in natural logarithms the exchange rate at time $\mathrm{t}, \mathrm{s}_{\mathrm{t}}$, is

$$
\mathrm{S}_{\mathrm{t}}=\mathrm{x}_{\mathrm{t}}+\mathrm{c}_{\mathrm{t}}
$$

where, again, $c_{t}$ is the central parity and $x_{t}$ is the proportionate deviation from parity. Taking time derivatives

$$
\mathrm{E}_{\mathrm{t}}\left[\mathrm{ds}_{\mathrm{t}}\right] / \mathrm{dt}=\mathrm{E}_{\mathrm{t}}\left[\mathrm{dx}_{\mathrm{t}}\right] / \mathrm{dt}+\mathrm{E}_{\mathrm{t}}\left[\mathrm{dc}_{\mathrm{t}}\right] / \mathrm{dt}
$$

Which says that the rationally expected rate of change of the exchange rate can be divided into the expected movement 'within the band', $\left(\mathrm{E}_{\mathrm{t}}\left[\mathrm{dx}_{\mathrm{t}}\right] / \mathrm{dt}\right)$, plus the expected rate of depreciation of the central parity, $\left(\mathrm{E}_{\mathrm{t}}\left[\mathrm{dc}_{\mathrm{t}}\right] / \mathrm{dt}\right)$.

Furthermore, for any given $\mathrm{x}_{\mathrm{t}}$, the movement within the band is bounded by the lower (strong) and upper (weak) intervention points

$$
\left(\mathrm{x}_{\mathrm{t}}^{1}-\mathrm{x}_{\mathrm{t}}\right) / \mathrm{dt} \leq \mathrm{E}_{\mathrm{t}}\left[\mathrm{dx}_{\mathrm{t}}\right] / \mathrm{dt} \leq\left(\mathrm{x}_{\mathrm{t}}^{\mathrm{u}}-\mathrm{x}_{\mathrm{t}}\right) / \mathrm{dt}
$$

where $\mathrm{x}^{1}$ is the lower bound of $\mathrm{s}_{\mathrm{t}}$, and $\mathrm{x}^{\mathrm{u}}$, the upper bound.

On using equations (9) and (10) we discover the confidence interval for realignment expectations 


$$
\left(\mathrm{i}_{\mathrm{t}}-\mathrm{i}{ }_{\mathrm{t}}\right)-\left(\mathrm{x}_{\mathrm{t}}^{\mathrm{u}}-\mathrm{x}_{\mathrm{t}}\right) / \mathrm{dt} \leq \mathrm{E}_{\mathrm{t}}[\mathrm{dc}] / \mathrm{dt} \leq\left(\mathrm{i}-\mathrm{i}^{*}\right)-\left(\mathrm{x}_{\mathrm{t}}^{1}-\mathrm{x}_{\mathrm{t}}\right) / \mathrm{dt}
$$

where $\mathrm{i}_{\mathrm{t}}$ is the home country's interest rate and $\mathrm{i}_{\mathrm{t}}$ is a comparable interest rate in the foreign country. The term $\left(\mathrm{i}_{\mathrm{t}}-\mathrm{i}_{\mathrm{t}}\right)$ - the interest differential - has been substituted for $\mathrm{E}_{\mathrm{t}}\left[\mathrm{ds}_{\mathrm{t}}\right] / \mathrm{dt}$ because we are assuming that uncovered interest parity holds. ${ }^{4}$ (The forward premium could have been used instead). Equation (11) defines the minimum and maximum bounds of the market's rationally expected central parity realignment. Svennson called this the 'simplest test' for realignment expectations.

A numerical illustration may be helpful. Suppose that a pegged exchange rate regime had a plus/minus $0.5 \%$ fluctuation band around its central parity, that the exchange rate happened to be at the centre of the zone (i.e. $\mathrm{x}_{\mathrm{t}}=0$ and, therefore, $\mathrm{x}_{\mathrm{t}}^{\mathrm{u}}-\mathrm{x}_{\mathrm{t}}=0.5 \%$ ), but that the expected change in the exchange rate as measured by the interest differential was $5 \%$. It follows that $4.5 \% \leq \mathrm{E}_{\mathrm{t}}[\mathrm{dc}] / \mathrm{dt} \leq$ $5.5 \%$ and we are confident that depreciation of the central parity is expected. Suppose again that the exchange rate is in the centre of its zone but that the expected depreciation is only $0.25 \%$. Thus, $0.25 \% \leq \mathrm{E}_{\mathrm{t}}[\mathrm{dc}] / \mathrm{dt} \leq 0.75 \%$. In this case the range of expectations spans both a possible appreciation of the central parity and a depreciation. As this range spans zero, the null hypothesis of no realignment cannot be rejected.

\section{Calculating realignment expectations: drift adjustment method}

Svensson complements the simplest test for realignment expectations with that of the 'drift adjustment method' which uses an econometric estimate of expected reversion of the exchange rate to parity within the target zone (Svensson, 1993, page 768).

Rearranging equation (9) obtains a statement of the rationally expected realignment expectation as:

\footnotetext{
4. As Svensson (1993 p. 766) points out, if agents arbitraging between national money markets demand a risk premium, the interest differential measures the expected change in the exchange rate plus the risk premium.
} 


$$
\mathrm{E}_{\mathrm{t}}[\mathrm{dc}] / \mathrm{dt}=\mathrm{E}_{\mathrm{t}}[\mathrm{ds}] / \mathrm{dt}-\mathrm{E}_{\mathrm{t}}[\mathrm{dx}] / \mathrm{dt}
$$

This realignment expectation can be calculated if the two terms on the right hand side are known. The expected change in the exchange rate, $\mathrm{E}_{\mathrm{t}}[\mathrm{ds}] / \mathrm{dt}$, is known from the interest differential, and Svensson (1993) gives a simplified method for calculating the expected movement of the exchange rate within the band. He takes this to be a linear function of the current deviation, $\mathrm{x}_{\mathrm{t}}$, of the exchange rate from the central parity. ${ }^{5}$ The expected movement of the exchange rate within the band, therefore is

$$
\mathrm{x}_{\mathrm{t}+\mathrm{m}}-\mathrm{x}_{\mathrm{t}}=\mathrm{a}_{0}+\mathrm{a}_{1} \mathrm{x}_{\mathrm{t}}+\mathrm{u}_{\mathrm{t}}
$$

i.e., the expected movement in the band depends on the current deviation from the centre of the band. And if $\mathrm{a}_{1}$ is significantly less than zero we have mean reversion. ${ }^{6}$

The final step in implementing equation (12) is to take the $95 \%$ confidence intervals for mean reversion - calculated using equation (13) - and to combine them with the interest rate differential (or forward premium) data, which proxy for $\mathrm{E}_{\mathrm{t}}[\mathrm{ds}] / \mathrm{dt}$, to calculate the '95\%' confidence intervals for realignment expectations.

\section{Classical and interwar gold standard regimes}

In this section we examine the 'classical' gold standard (circa 1875-1914), the inter-war gold standard (circa 1925-1931), and the last vestiges of the gold standard operating by the gold bloc (1933 to 1936) as pegged exchange rate regimes.

What are the main reasons for the success of the classical system? According to Gallarotti (1995) one reason is the dominant political philosophy of the day, laissez faire - which allowed markets to

\footnotetext{
${ }^{5}$. It is possible to make this assertion because according to Krugman (1988) in a credible target zone the exchange rate should be mean reverting.

6 Notice that equation (10) is in the form of a test for a unit root, where $\mathrm{a}_{1}=\rho-1$.
} 
'work', discouraged fiscal deficits, and favoured monetary discipline. Also the UK, as the world's dominant economic and financial power, acted beneficially for the international monetary system. She was the main source of long-term capital loans - lending long and borrowing short as long term capital outflows exceeded her current account surpluses (Lindert, 1969). The UK also practiced free trade, so allowing other countries to repay international debts in commodities rather than gold. Thus, the UK did not drain gold from debtor nations, rather, she promoted the reflow of international finance (Morgan-Webb, 1934). This contrasts with the experience of the inter-war gold standard when both the US and France drained gold from other members of the system.

According to Cassel (1935) the classical gold standard was successful because it was a sterling standard: "the pre-[first world] war gold standard may not inadequately be described as a sterling bloc held together by London's position as the world's financial centre and by the pound sterling as a generally recognized means for international payments". ${ }^{7}$ Sterling balances held in London economized on gold and were used to settle international balances. World trade was largely financed in sterling bills of exchange drawn on British banks. Lindert (1969) points out that by 1913, foreign exchange (including some French francs and German marks) made up about 19 percent of the world's 'gold and foreign exchange' reserves, rising from about 10 percent in 1880. Thus, classical gold standard was really a gold-exchange standard, with sterling as the key currency.

However, London was not the "conductor of the international orchestra" with the Bank of England setting interest rates for the system as a whole. Rather as Eichengreen and Flandreau (1996) point out it was a multi-polar system with London, Paris and Berlin having their own spheres of influence. Furthermore, tracing Granger 'causality' between changes in central bank discount rates Tullio and Wolters (1996) show that the Bank of England often followed discount rate changes in

\footnotetext{
${ }^{7}$. Quoted by Bordo, 1983, page 75-6.
} 
Germany and, sometimes, in Paris. Besides, as an open pegged system the monetary approach to the balance of payments applied and money in the UK was endogenous (McCloskey and Zecker, 1976). Although not widely recognized, the same also applied to the USA in 1929-33 - and the Great Depression there had international causes - see below.

The key factor in the success of the classical gold standard was that it was a credible system. Financial markets seem to have been convinced that the pound, franc and mark would not be devalued, and this set up a virtuous interaction: exchange rate credibility promoted stabilizing shortterm capital flows which helped to stabilize exchange rates. It was not the size of the UK's gold reserve that bred confidence in the key currency, rather it was the Bank of England's dexterity in managing its bank rate to this end that was the crucial factor. Bloomfield (1959) and Goodhart (1972) show than bank rate was managed procyclically - in order to reduce long-term capital outflow when the current account weakened with economic expansion.

\section{Credibility and short-term capital flows}

Figure 1 shows the dollar-sterling fluctuation-band, or, 'target zone' for The Economist's contemporaneous estimate and one by Clark (1984). The fact that the dollar-pound exchange rate sometimes penetrated these estimated gold points does not necessarily mean that they did not set credible bounds to the exchange rate. This is because the gold points almost certainly varied over time - for instance, as interest rates changed. 


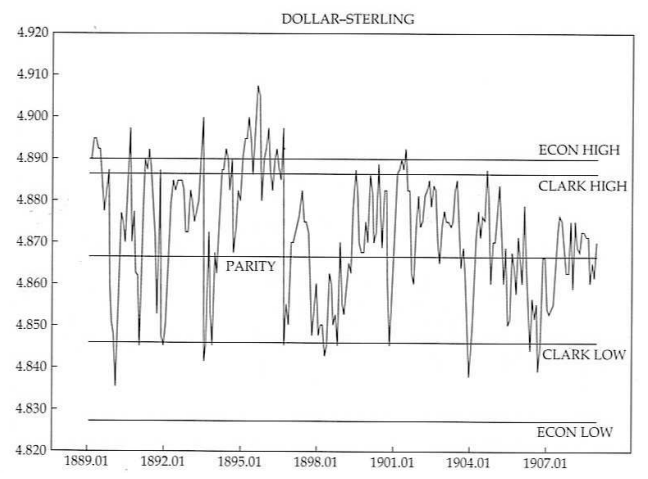

Figure 1: Spot rate and gold points

In the target zone theory of Krugman (1988) exchange rates between the gold points should be mean reverting - movement of an exchange rate near one of the gold points should be back towards the centre of the zone. That is, in an AR(1) process, $\rho$ should be significantly less than unity. The time series of exchange rates should be a stationary process. For this to be so, it must be the case that the fundamental determinants of an exchange rate should not leave a currency permanently weak at the gold export point (or strong at the gold import point). Variance ratio and unit root tests of the US dollar-pound and French franc-pound exchange rates, 1889-1908, indicate strong evidence of mean reversion (Hallwood, MacDonald, and Marsh, 1996).

Another test for the credibility of commitment is to use uncovered interest parity to test the prediction that the difference between a pair of comparable short-term interest rates in two countries, should not deviate by more than the maximum allowable movement of the exchange rate 'within the band'. If the deviation in these interest rates is any greater than this, then 'the market' is deemed to expect an exchange rate realignment.

Realignment expectations for the franc-pound and dollar-pound exchange rates are reproduced, respectively, as figures 2 and 3. The two lines in each figure are 95 percent confidence intervals. Only when both are of the same sign (e.g. above the zero line) are realignment expectations taken to 
be statistically significant.

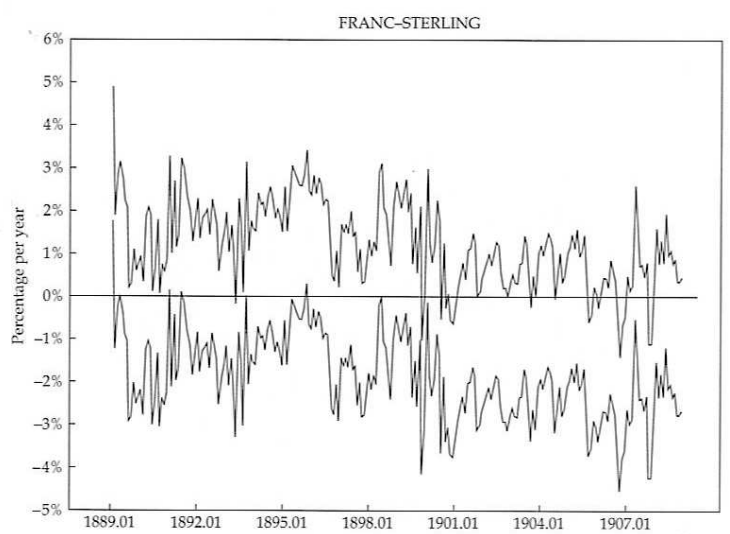

When both confidence intervals are positive, franc devaluation is expected; vice versa for the pound. If they are of opposite sign accept statistically that no realignment is expected.

Figure 2: Realignment expectations for the franc-pound exchange rate.

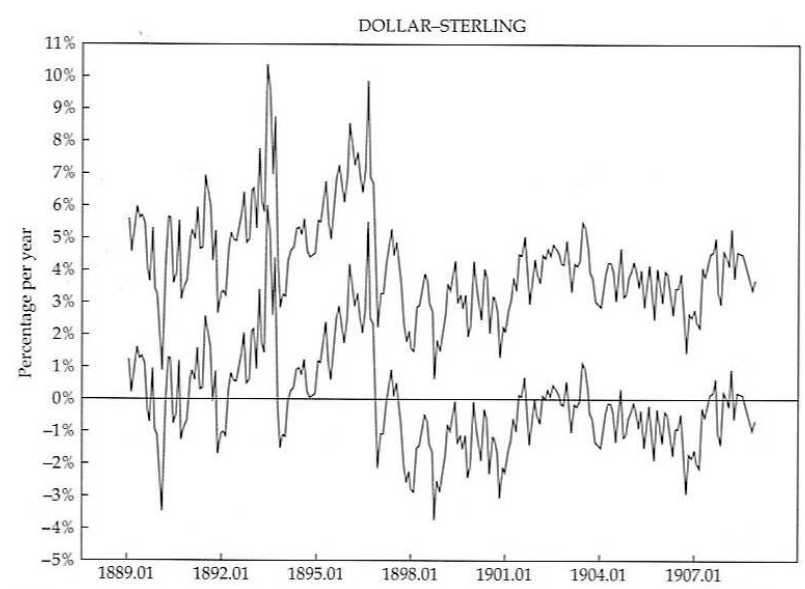

When both confidence intervals are positive, franc devaluation is expected; vice versa for the pound. If they are of opposite sign accept statistically that no realignment is expected.

Figure 3: Realignment expectations for the dollar-pound exchange rate. 
The striking fact about the franc-pound exchange rate is that markets rarely questioned the gold commitment in either France or the UK. ${ }^{8}$ The case of the US dollar is somewhat different as until 1896 the dollar was often expected to devalue (a significant positive realignment expectation). The USA's political commitment to the gold standard was threatened by the 'free silver movement' which wanted the remonetization of silver. The defeat of the Democratic 'free silver' candidate, William Jennings Bryan, in the election of 1896 marks the end of significant dollar realignment expectations in figure 3 .

\section{Inter-war period}

Dozens of countries, following the British lead in April 1925, rejoined the international gold standard only to abandon gold six years later. The USA hung on until March 1933, and France and a few other 'gold block' countries until September 1936.

While the inter-war 'experiment' with gold is often disparaged, it is a remarkable fact that exchange rates of some important European currencies fared as well as or better than they did under the European Monetary System. Officer (1993) has calculated gold points for the pound against the dollar and found that they were never challenged. Realignment expectations as calculated using the foregoing methodology are for the pound during the interwar gold standard are reproduced in figure 4. They only turned to favor a devaluation of the pound against the dollar (both confidence intervals positive) in the summer of 1931 - just before gold was in fact abandoned in September. Thus, financial markets, it seems, deemed the UK's adherence to the gold standard as a credible commitment, and short term capital flows, at least until almost the very end, must not have been

\footnotetext{
${ }^{8}$ Mundaca (2004)argues that the drift adjustment methods understates the extent of realignment expectations because the frequency of actual realignments may be less than the frequency of expected realignments. This is a sort of 'peso problem' - expectation of a devalution that does not happen. That a peso problem might be present in our data is indicated by the fact that sometimes the forward exchange rate lay outside of the fluctuation band. The upshot of this is that our calculations might somewhat understate the strength and frequency of realignment expectations, but on the basis of Mundaca's findings we do not think there is much difference.
} 
particularly destabilizing of the pound-dollar exchange rate. The fact that the time series for the pound-dollar exchange rate was mean reverting - in accordance with target zone theory - supports this conclusion.

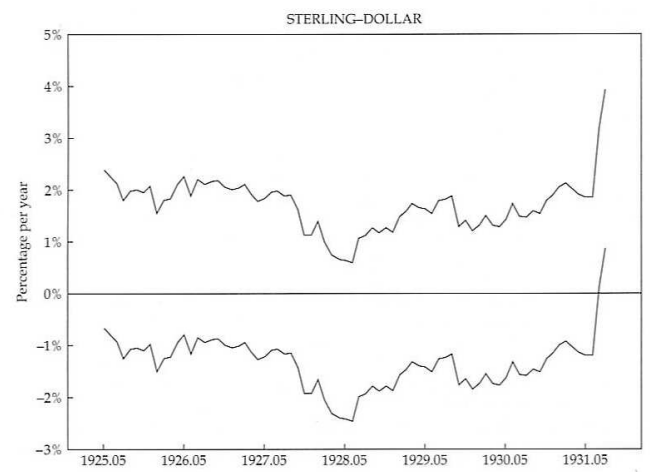

When both confidence intervals are positive, franc devaluation is expected; vice versa for the pound. If they are of opposite sign accept statistically that no realignment is expected.

Figure 4: Inter-war realignment expectations, pound-dollar exchange rate

USA suspended gold convertibility eighteen months after Britain in March 1933. Figure 5

measures realignment expectations for the franc-dollar exchange rate. As the franc remained on gold, the series here also measures the credibility of the American commitment to gold. In this case, when both confidence intervals are below the zero line markets are deemed to expected a devaluation of the dollar. ${ }^{9}$ Comparing figures 4 and 5 it can be seen that the struggle to 'save the dollar' was a much more drawn out affair than that to 'save the pound'.

${ }^{9}$. As the exchange rate here is the franc-dollar rate, if 'the market' expects a devaluation of the dollar, there will be fewer francs per dollar. 


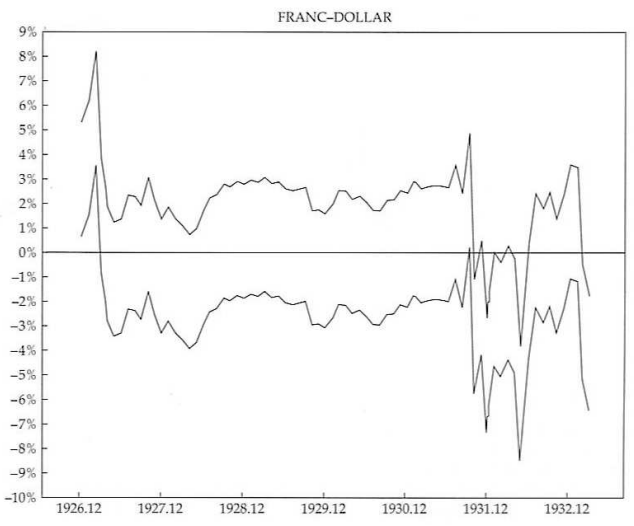

If both confidence intervals are positive the dollar is expected to devalue.

Figure 5: Franc-dollar realignment expectations.

\section{Playing by the 'rules of the game'}

Did central banks play by 'the rules of the game' in letting the foreign account to a large extent determine changes in base money, or did they set other objectives such as targeting domestic monetary conditions? Eichengreen, Watson and Grossman (1985) find that the Bank of England did not play by the rules, as bank rate was keyed onto domestic business conditions. Hallwood, MacDonald and Marsh (1996) regress their time-series of pound-dollar realignment expectations on key macroeconomic variables - see table 2 - and find that they were sensitive to monetary policy. Yet it remains true that realignment expectations did not (in a statistical sense) favor a devaluation of the pound until just before the end. 


\begin{tabular}{lcc}
\hline & UKIUS & FR/US \\
\hline$r-r^{*}(-1)$ & -0.012861 & 0.000568 \\
$\pi-\Pi^{*}(-1)$ & $(2.42)$ & $(0.15)$ \\
& -0.678636 & -0.175159 \\
$m-m^{*}(-1)$ & $(2.24)$ & $(3.01)$ \\
& 0.073279 & -0.002736 \\
bop-bop ${ }^{*}(-1)$ & $(3.46)$ & $(0.22)$ \\
& 0.007605 & -0.005111 \\
$y-y^{*}(-1)$ & $(2.95)$ & $(1.78)$ \\
& -0.006547 & 0.010847 \\
real(-1) & $(3.02)$ & $(1.78)$ \\
& 0.536438 & 0.710324 \\
$E[$ dc $] / d t(-1)$ & $(2.02)$ & $(1.94)$ \\
& 0.726229 & 0.713541 \\
$R^{2}$ & $(10.97)$ & $(10.00)$ \\
Std. error & 0.849 & 0.882 \\
$X^{2}$ test & 0.0033 & 0.0034 \\
No. observations & $25.071(0.00)$ & $76.899(0.00)$ \\
\hline
\end{tabular}

Figures in parentheses under the coefficient estimates are $t$-statistics computed with GMM standard errors. $r$ denotes reserves, $\pi$ denotes inflation, $m$ denotes money supply, bop denotes the balance of payments (exports/imports), $y$ denotes income, and real denotes the real exchange rate. All independent variables are lagged by one period, and $\mathrm{a}^{*}$ denotes a foreign (US) variable. $X^{2}$-tests are tests that the fundamental determinants excluding the lagged dependent variable are insignificant. The figures in parentheses after the test statistics are the marginal significance level.

Table 2 Fundamental determinants of realignment expectations, pound-dollar, 1925-1931.

There is no paradox. Since an exchange rate is free to vary within the fluctuation band, the exchange rate commitment does not mean that a central bank cannot practice limited monetary management. Indeed, it is recognized that the wider exchange rate bands of the Bretton Woods system would allow precisely this. Thus, since markets deemed the pound-dollar rate credible, the conclusion should be that for all but about the last two months of the 1925-31 period that the UK was on gold, the Bank of England did play by the 'rules of the game'.

\section{The gold standard and the Great Depression in the USA}

Did monetary contraction and depression in the USA result from unconstrained Federal Reserve policy, or was the Fed and the US a victim of the commitment to gold? Friedman and Schwartz (1963) argue that the gold standard commitment was not a factor in the American monetary 
contraction because the Fed had plenty of gold. ${ }^{10}$ Brown (1940), Eichengreen (1992), Kindleberger (1986) and Temin (1989) argue the opposite case but their evidence is rather inconclusive. An attempt to settle this matter is that of Hallwood, MacDonald and Marsh (1997 and 2000).

There are three key magnitudes: realignment expectations on the value of the dollar, gold flows between the US and the rest of the world, and American bank failures. Hallwood, MacDonald and Marsh (1997) use Granger 'causality' tests and vector autoregressions to determine the direction of causality between them. Their evidence on US monetary policy and international interactions supports the argument that the Federal Reserve's monetary policy was indeed constrained by international considerations. specifically, the fact that bank failures caused with a lag (on both the Granger causality and VAR tests) dollar devaluation expectations suggests a domestic cause of the weakening of the USA's adherence to the gold standard. In other words, even more stringent monetary contraction (the very thing that the Fed has been blamed for by Friedman and Schwartz), and resulting bank failures, would have caused even greater fragility of the dollar on the foreign exchanges. Even more significantly for the 'international cause' argument is that there is a positive feedback from gold outflows to bank failures (a lagged effect on the Granger causality tests and a contemporaneous effect from the VAR). That is, an international interaction was adversely affecting the US banking system. Furthermore, gold outflows were having a lagged effect on dollar devaluation expectations (this time from both of our tests), which must also have been a worry for the Fed. These findings would seem to support the positions of Eichengreen, Kindleberger and Temin rather than that of Friedman and Schwartz. The Federal Reserve was indeed being hemmed in by the USA's commitment to the gold standard. The Federal Reserve found itself in a dilemma: if it increased the money base to 'save the banks', which it did try to do with open market purchases

\footnotetext{
${ }^{10}$. Friedman and Schwartz (1963) wrote "that a shortage of free gold did not in fact seriously limit the alternatives to the [Federal Reserve] System. The amount was at all times ample to support large open market purchases... The problem of free gold was largely an ex post justification for policies followed, not an ex ante reason for them (page 406).
} 
in the spring and early-summer of 1932, it was not playing by the 'rules of the game' given the preponderance of gold outflows between September 1931 - when sterling left gold - and June 1932. However, if it did nothing, which turned out to be the preferred policy, this risked the bank failures that, as we have shown, also put pressure on the dollar. Under these circumstances the USA's adherence to the gold standard had become untenable. Remarkably these results are fully consistent with the hypothesis of Brown (1940) that devaluation expectations caused a withdrawal of gold which in turn precipitated waves of bank failures.

\section{Demise of the gold bloc, 1933-1936}

The gold bloc grew out of the failure of the World Economic Conference in June 1933 to reconstitute an international gold standard following the USA's suspension of it in March - but Roosevelt would have nothing to do with it. Thus it was that Belgium, France, Netherlands and Switzerland (and, initially a few peripheral players) formed the 'gold bloc'.

An interesting question about the gold bloc concerns what ultimately brought it down. Is its failure just one more piece of evidence against pegged exchange rates and independent national monetary policies, or, were other factors at work? Eichengreen (1992) and Hogg (1987) give similar purely politico-economic explanations centering on their currency over-valuation vis a vis the dollar and pound and resulting balance of payments deficits and gold loss. Thus, to protect their gold reserves, the gold bloc countries were forced to deflate their price levels with resulting very high rates of unemployment. This explanation for abandonment of the gold standard closely resembles that which seems to explain the UK's abandonment of gold 5 years earlier. Moreover, the fact that Belgium was embroiled in a major banking crises as well as straitened economic circumstances when it devalued against gold in March 1935 has a resemblance to the circumstances under which the USA had suspended gold. 
However, the European political landscape had changed mightily in the few years to 1937, in particular, there was the rise of the Third Reich. It is worth noting that the classical gold standard operated in Europe at a time when a balance of power held and that it was promptly abandoned in 1914 when that balance cracked. Throughout the inter-war period the European balance of power was far from being stable, the French having been left by the Americans and the British to face Germany virtually alone - French alliances with various East European nations being of little military value.

Important political-military events occurred in March 1935 when Germany announced the reintroduction of conscription - which was against both the Versailles Treaty and the Locarno Pact; October 1935 when Italy invaded Abyssinia (which for complicated reasons destroyed any protection that France might have enjoyed under the League of Nations and the principle of 'collective security' - see Kissinger (1994); and March 1936 when Germany reoccupied the Rhineland, so eliminating France's surrogate buffer state and access to its Eastern European allies. At the time of the latter event, the French Foreign Minister Flandin commented that "once Germany had fortified the Rhineland Czechoslovakia would be lost and that, soon after, general war would become unavoidable" (quoted by Kissinger, 1994, p. 305). It can hardly be argued, therefore, that the second world war broke on the France as a complete surprise, indeed, it was signalled well ahead of the outbreak.

Concurrent financial events in France can be linked to these political-military developments: the financially conservative Laval government fell over the Abyssinian debacle; in March 1936 there was a run on the banks in north and north eastern France (Einzig, 1937); French investors moved gold to London bank vaults, presumably for safe keeping; and an increase in French defence spending equal to about a third of French gold reserves was announced just two weeks before gold was abandoned. 
Hallwood, MacDonald and Marsh (2007) examine the demise of the Gold Bloc through a comparison of external versus internal inconsistency hypotheses. The external inconsistency hypothesis, associated with many investigators (see in particular Eichengreen, 1992), says that gold bloc currencies were over-valued, and were deepening the depression in its member countries. The internal inconsistency hypothesis is that growing probability of another Franco-German war differently impacted the member countries. Thus, from at least early-1936 financial capital flowed out of France, weakening its peg to gold, while Switzerland, most likely to be a neutral country in any coming war, experienced no such problems - at least not on a major scale. Support for the internal inconsistency hypothesis is found in the behavior of the French interest rate yield curve versus that of Switzerland (and to a less extent the Netherlands). French long rates increased relative to short rates as investors lost confidence in investing in France, but the same did not happen in Switzerland.

\section{Calculating devaluation probabilities}

Another use of the target zone model is to break expectations into their components. Thus, the expected rate of realignment, measured as the interest rate differential, can be interpreted as the expected devaluation size multiplied by the frequency of realignment.

To illustrate, suppose that, conditional on there being a devaluation, the devaluation will be 5\%. An expected rate of realignment of $2.5 \%$ implies that the expected frequency of realignment is 0.5 per annum. That is, the market expects 5\% devaluation within the year to happen with a 50\% probability. Equivalently, the expected time to a 5\% devaluation of a currency is two years. Thus, though the average expected rate of realignment may appear to be small it can be consistent with quite substantial devaluation expectations. 
Following Mizrach (1995) the realignment expectation is determined as follows

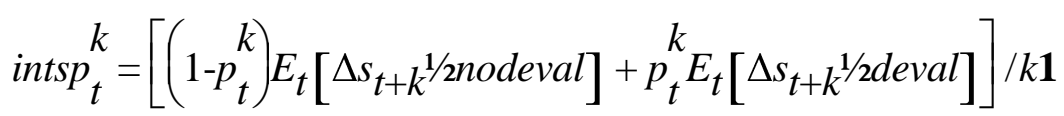

where $i n t s p_{t}^{k}$ denotes the interest rate differential, or realignment expectation (home minus foreign country's) on bills of maturity $k$ years, $p_{t}{ }^{k}$ denotes the time $t$ probability of a realignment (home currency devaluation) during the subsequent $k$ years, and $s_{t}$ denotes the spot exchange rate. What this equation says is that the interest differential equals the probability weighted change in the spot exchange rate under the alternative scenarios of devaluation and no devaluation.

There are four independent terms in equation (14) - the interest differential, the expected change in the exchange rate conditional on no devaluation, the expected change in the exchange rate conditional on devaluation, and the probability of realignment. The one that we are after is the probability of devaluation, $\rho_{\mathrm{t}}^{\mathrm{k}}$, which can be isolated if the other three independent terms are known or can be proxied.

The easiest one to calculate is obviously the interest rate differential, but care must be taken to use comparable interest rates. The term $\mathrm{E}_{\mathrm{t}}\left[\Delta \mathrm{s}_{\mathrm{t}+\mathrm{k}} \mid\right.$ nodeval $]$ is simply the movement of the exchange rate within the band which can be modeled as in equation (13). This leaves $\mathrm{E}_{\mathrm{t}}\left[\Delta \mathrm{s}_{\mathrm{t}+\mathrm{k}} \mid \operatorname{deval}\right]$ which Mizrach (1995) models as a linear function of the size of the last devaluation. Other methods can also be used to estimate the size of the latter term, for example making it proportional to the deviation of an exchange rate from purchasing power parity.

Having recovered the time series of probabilities of devaluation from equation (14) it is then possible to regress $\rho_{\mathrm{t}}{ }^{\mathrm{k}}$, on its determinants. The set of determinants of the probability of devaluation includes things such as macroeconomic fundamentals, interest rate term structures and, perhaps dummy variables to capture political or other non-economic events. 
As an example of the application of the Mizrach (1995) model, Hallwood, MacDonald and Marsh (2000b) apply it to the USA during the period 1890-1908 when, for part of this period, American continued adherence to the gold standard was in doubt. We use two dummies to capture the effects on the probability of realignment of, first, the Silver Purchase Act, 1890-1893 (which partly untied the US money base from gold) and, secondly, political pressure for a return to a bimetallic silvergold standard which lasted from at least 1890 until the defeat of the silver candidate in the presidential election of November 1896. We also use three fundamentals: the relative (US minus UK) year-on-year growth rates of money (measured as notes and coin in circulation), relative yearon-year income growth rates, and the real exchange rate. All fundamentals being lagged one period. The first dummy takes a value of one if the Silver Purchase Act is on the US statutes (1890/7 1893/10) and a zero otherwise. The second dummy takes a value of one if the bimetallism debate is still active in the US, defined as the period from the start of our sample, $1890 / 1$ to $1896 / 11$.

Our results are illustrated in figure 6 where it is shown that the probability of dollar devaluation peaks at about the time the 1890 Act was repealed, and again at the time of the 1896 presidential election - which turned out to be closely run. That the dollar was under pressure on the exchanges mainly because of political factors is evident from the dashed line which nets out silver risk - in other words US macro-fundamentals were not out of line with the commitment to the gold peg.

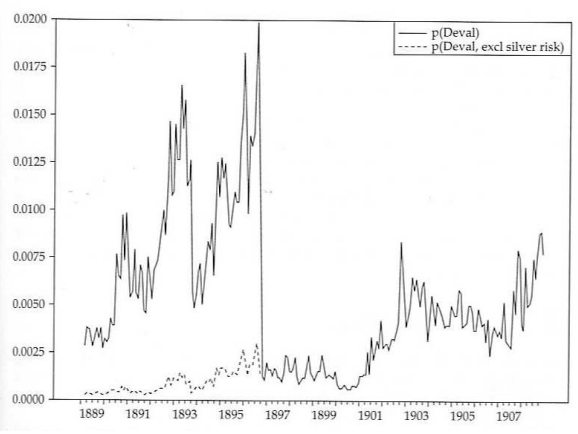

Figure 6: Probability of dollar devaluation 1889-1908 
The probability of dollar devaluation falling sharply after 1896 can be interpreted as a long-lasting shift in sentiment in favour of dollar. It has been a puzzle for a hundred years as to why the Fisher equation for real interest parity apparently did not hold after 1896 and into the early- years of the twentieth century. With real interest parity the Fisher equation predicts that a rise in a country's inflation differential will cause its interest rate differential likewise to increase - so keeping real interest rates between a pair of countries unchanged. Yet during this period US inflation increased relative to that in the UK but the US interest differential over UK rates did not. This fall in US real interest rates relative to UK rates is entirely consistent with a shift in sentiment in favour of the dollar - speculators turing to demand a lower real return on short-term dollar denominated assets.

\section{Dirty floating}

The term 'dirty floating' refers to the fact that an exchange rate is ostensibly floating yet, at irregular intervals, it subjected to intervention by the exchange authorities. Virtually all exchange rates that 'float' do so in this manner. While the theories of target zones and dirty float appear to be concerned with quite different subjects this is in fact not the case. The theories of target zones and dirty floating both combine elements of exchange market intervention and a floating exchange rate. Thus, within the intervention points of a target zone the exchange rate may be left free to float. Under dirty floating exchange market intervention by the authorities is more discursive as there are no formal intervention points, never-the-less floating and intervention are combined.

The term 'dirty floating' was used soon after the general move to floating exchange rates in the early-1970s. What it means is that a monetary authority states an official policy of letting the exchange rate float, yet frequently intervenes in the foreign exchange market to manage the exchange rate.

Perhaps dirty floating is best analyzed using the exchange pressure model of Girton and Roper 
(1977). In this model demand and supply for base money are always equal. Thus,

$$
\mathrm{H}=\mathrm{F}+\mathrm{D}=\mathrm{PY}^{\beta} \exp ^{-\alpha \mathrm{i}} \quad \beta, \alpha>0
$$

where $\mathrm{H}$ is the money base, $\mathrm{F}$ is foreign exchange reserves, $\mathrm{D}$ domestic securities held by the central bank, and $\mathrm{PY}^{\beta} \exp ^{-\alpha \mathrm{i}}$ a Cagan-style money demand function.

Writing the last equation in logs, taking time derivatives and noting that $\mathrm{F}$ and $\mathrm{D}$ are both expressed as proportions of $\mathrm{H}$, gives

$$
\mathrm{f}+\mathrm{d}=\pi+\beta \mathrm{y}-\alpha \mathrm{i}^{\prime}
$$

where all variables are expressed as rates of change in, respectively, reserves, domestic securities (known as domestic credit expansion, or, DCE), the price level, real income, and the rate of interest.

To find the international consequence of DCE, inflation etc. subtract the foreign country variables from these home country variables, giving

$$
f-f^{*}=-d+d^{*}+\beta y-\beta^{*} y^{*}+\pi-\pi^{*}-\alpha\left(i^{\prime}-i^{* \prime}\right)
$$

Now add e - the rate of appreciation of the exchange rate (stated as the amount of foreign currency per unit of home currency, so an increase is an appreciation) to both sides of the last equation to give

$$
f-f^{*}+e=-d+d^{*}+\beta y-\beta^{*} y^{*}+q-\alpha\left(i^{\prime}-i^{*}\right)
$$

where $\mathrm{f}-\mathrm{f}^{*}+\mathrm{e}$ is dubbed 'exchange market pressure' (EMP), an decrease in EMP signifying an increase in 'pressure' against a monetary authority (as the rate of increase in foreign exchange reserves and/or appreciation of the currency has fallen); and $\mathrm{q}\left(=\pi-\pi^{*}+\mathrm{e}\right)$ is the rate of appreciation of the real exchange rate. Thus, EMP increases with an increase in the home country's 
rate of DCE or rate of interest (both of which inducing dishoarding); and it decreases with an increase in the rate of growth of real income and the real exchange rate (both of which inducing hoarding).

Notice that with a floating exchange rate the monetary authority can choose how to absorb shocks to the RHS variables: it can let either f or e or both change. If the authority does not want the exchange rate to move too much (because, for example, it does not want a lot of volatility), it can use its foreign exchange reserves. Alternatively, if it is targeting reserves, it can let e 'take the strain'.

The EMP model is relevant when a country contains its exchange rate within an official fluctuation band or 'target zone'. The authorities can allow the exchange rate to float freely within the upperand lower-edges of the zone; only necessarily having to intervene with foreign exchange reserves when the exchange rate threatens to penetrate either edge.

Girton and Roper (1977) test the EMP for the Canadian-US dollar. They treat Canada as a small country and estimate the equation

$$
r_{c}+e_{c}=\beta_{0}+\beta_{1 c} d_{c}+\beta_{2 u s} h_{u s}+\beta_{3 c} y_{c}+\beta_{4 u s} y_{u s}+v
$$

where, respectively, 'c' and 'us' stand for Canada and the USA; and the expected signs are $\beta_{1 \mathrm{c}}<0$, $\beta_{2 u s}>0, \beta_{3 c}>0$, and $\beta_{4 u s}<0$. In their linear regression of this equation the expected signs are found at high levels of significance.

Hallwood and Marsh (2004) test equation (18) using monthly data for the interwar gold standard period. The gold standard, while often viewed as a fixed rate system in fact featured a fluctuation band (defined by the gold points). The results are reported in table 3 . The dependent variable is 
exchange market pressure and the exchange rate is the pound/dollar rate. ${ }^{11}$

Significantly, an increase in realignment expectations, $\Delta E\left[d c_{t}\right] / d t$, increased pressure against the pound. This pressure, according to the definition of exchange market pressure, taking the form of depreciation of the pound within the band, or a reduction in foreign exchange reserves to protect the pound, or both. $^{12}$

Column A of table 3 details the results of the most rigid interpretation of equation (18). The coefficient on UK domestic credit growth is statistically significant, correctly signed and not far from its theoretical value of minus unity (a test of this restriction cannot be rejected - see $H 1$ ). US domestic credit growth and relative income growth rates are both insignificant (though correctly signed). The coefficient on the real exchange rate term carries the correct sign and is significantly different from both zero and its theoretical value of minus unity $(H 2)$. Finally, the coefficient on the change in our proxy for the interest differential, $\delta$, is also significant and correctly signed. Column B of table 2 loosens the restriction that the income elasticity of demand for money is equal in the two countries. There are two points to note. First, the

\footnotetext{
${ }^{11}$ As our methodology does not assume that EMP can to some degree be eased by monetary contraction - nonsterilized intervention, aimed at supporting the balance of payments at the current exchange rate peg, it tends to underestimate the degree of EMP on a currency. To take account of monetary intervention the elasticity of the domestic price level with respect to the exchange rate, and the interest elasticity of demand for money must be calculated. Only if the sum of these differs from unity does EMP as calculated here differ from that calculated taking these two elasticities into account. Kohlscheen $(2000)$ applies the Weymark $(1997,1998)$ method to data for Chile in the 1990s. While he finds that calculated EMP differs between the two methods the signs of EMP are always the same, and not very different in magnitude. This is because the sum of the two elasticties do not differ much from zero, which would be the case if purchasing power parity holds approximately, and the elasticity of demand for money with respect to the nominal exchange rate is low.

${ }^{12}$ The equations presented in table 3 were estimated using the McCallum-Wickens instrumental variables technique. In each case the dependent variable is exchange market pressure and the exchange rate is the pound-dollar rate. The instrument set is the dependent and each explanatory variable lagged by two and three periods, together with a constant and a time trend. The figures in parentheses under the coefficient estimates are $t$-statistics computed with Newey-West GMM standard errors, robust to serial correlation and heteroskedasticity.
} 
coefficient on US (UK) income growth is significantly positive (insignificantly negative). Second, the coefficient on the real exchange rate is now insignificantly different from its hypothesized value.

In columns $\mathrm{C}$ and $\mathrm{D}$ we decompose changes in the interest rate differential proxy into changes in the expected movement of the exchange rate within the band, $\Delta E\left[d x_{t}\right] / d t$, and changes in the expected rate of devaluation of the pound, $\Delta E\left[d c_{t}\right] / d t$. Both of these factors are expected to affect exchange market pressure on the Bank of England, though perhaps not equally. With equal and opposite signs imposed on income growth in the two countries (column C), the two new terms are both negative and statistically significant while the other coefficient estimates are essentially unchanged from the baseline regression in column A.

Removing the restriction on income growth we obtain the results in column D. The adjusted coefficient of determination is highest in this version of the model while the standard error of the equation is the lowest, suggesting this to be the statistically preferred specification. Coefficient estimates are little changed from the regression in column B. Thus, an increase in the UK's rate of domestic credit expansion, $\Delta d_{t}$, increases exchange market pressure, as do changes in the macroeconomic variables - the UK's real exchange rate, $\theta_{t}$, and faster economic growth in the US. The joint hypothesis that the coefficients on UK domestic credit growth and the real exchange rate term are both equal to -1 cannot be rejected. The rate of US domestic credit expansion has the correct sign but is insignificant in every specification of the regression. Perhaps this is due to the well known fact that during the period the USA was not playing by the rules of the game since it was sterilizing the effect of its payments surpluses on its money base. 
What is most interesting about this last regression is the correct and significant signs on $\Delta E\left[d x_{t}\right] / d t$ and $\Delta E\left[d c_{t}\right] / d t$. is that a rise in $E\left[d c_{t}\right] / d t$ - an increase in either the probability or the magnitude of the expected devaluation of the pound - is encouraging capital outflows which in turn are pressuring the Bank of England to intervene. Importantly, this speculative pressure is additional to the pressure exerted by the fundamental variables in the regression equation; the rates of domestic credit expansion and real income growth in the UK and the USA, and the real exchange rate. 
Table 3: Exchange market pressure on the pound-dollar exchange rate: 1925 - 1931

\begin{tabular}{|c|c|c|c|c|}
\hline & (A) & (B) & (C) & (D) \\
\hline Constant & $\begin{array}{l}-0.001 \\
(1.177)\end{array}$ & $\begin{array}{l}-0.0001 \\
(0.132)\end{array}$ & $\begin{array}{l}-0.001 \\
(1.256)\end{array}$ & $\begin{array}{l}-0.0002 \\
(0.327)\end{array}$ \\
\hline$\Delta d$ & $\begin{array}{l}-1.240 \\
(2.195)\end{array}$ & $\begin{array}{l}-1.366 \\
(2.408)\end{array}$ & $\begin{array}{l}-1.398 \\
(2.431)\end{array}$ & $\begin{array}{l}-1.460 \\
(2.822)\end{array}$ \\
\hline$\Delta d^{*}$ & $\begin{array}{c}0.083 \\
(0.716)\end{array}$ & $\begin{array}{c}0.069 \\
(0.538)\end{array}$ & $\begin{array}{c}0.095 \\
(0.798)\end{array}$ & $\begin{array}{c}0.101 \\
(1.001)\end{array}$ \\
\hline$\Delta y-\Delta y^{*}$ & $\begin{array}{c}0.001 \\
(0.032)\end{array}$ & & $\begin{array}{l}-0.003 \\
(0.798)\end{array}$ & \\
\hline$\Delta y$ & & $\begin{array}{c}0.009 \\
(0.351)\end{array}$ & & $\begin{array}{c}0.002 \\
(0.117)\end{array}$ \\
\hline$\Delta y^{*}$ & & $\begin{array}{l}-0.306 \\
(1.996)\end{array}$ & & $\begin{array}{c}-0.272 \\
(1.980)\end{array}$ \\
\hline$\theta$ & $\begin{array}{l}-0.416 \\
(2.883)\end{array}$ & $\begin{array}{l}-0.824 \\
(3.404)\end{array}$ & $\begin{array}{l}-0.501 \\
(3.466)\end{array}$ & $\begin{array}{l}-0.849 \\
(4.157)\end{array}$ \\
\hline$\delta$ & $\begin{array}{l}-9.086 \\
(3.524)\end{array}$ & $\begin{array}{l}-9.477 \\
(3.692)\end{array}$ & & \\
\hline$\Delta E[d x] / d t$ & & & $\begin{array}{l}-2.300 \\
(4.542)\end{array}$ & $\begin{array}{l}-2.087 \\
(5.375)\end{array}$ \\
\hline$\Delta E[d c] / d t$ & & & $\begin{array}{l}-1.690 \\
(2.472) \\
\end{array}$ & $\begin{array}{l}-1.797 \\
(2.445) \\
\end{array}$ \\
\hline Adj- $R^{2}$ & 0.053 & 0.002 & 0.192 & 0.304 \\
\hline $\begin{array}{l}\text { Standard } \\
\text { error }\end{array}$ & 0.0055 & 0.0057 & 0.0051 & 0.0047 \\
\hline Q-statistic & 22.61 & 17.18 & 29.40 & 23.64 \\
\hline P-value & 0.26 & 0.58 & 0.06 & 0.21 \\
\hline$H 1$ & 0.67 & 0.52 & 0.49 & 0.37 \\
\hline$H 2$ & 0.00 & 0.00 & 0.00 & 0.00 \\
\hline H3 & 0.00 & 0.47 & 0.00 & 0.46 \\
\hline$H 4$ & 0.00 & 0.30 & 0.00 & 0.19 \\
\hline
\end{tabular}

Notes: $\Delta d$ denotes the growth of domestic credit (domestic credit defined as base money less reserves), and $\Delta y$ denotes the growth in income as proxied by industrial production. An asterisk denotes a foreign (US) variable. $\theta$ is the UK's real exchange rate, and $\delta$ denotes the growth in the interest rate differential as proxied by the forward premium. $\Delta E\left[d x_{t}\right] / d t$ and $\Delta E\left[d c_{t}\right] / d t$ denote respectively changes in the expected movement of the exchange rate within the band and changes in devaluation expectations. The figures in parentheses beneath the parameter estimates are $t$-statistics derived using GMM standard errors robust to serial correlation and heteroskedasticity. Some descriptive and diagnostic statistics are reported beneath the parameter estimates. Adj- $\mathrm{R}^{2}$ gives the adjusted coefficient of determination. The next row gives the standard error of the estimated equation. Q-statistic denotes the Q-test for serial correlation of up to 19 lags, and the P-value statistic gives the significance level of the Qstatistic. The figures $H 1-H 4$ denote the significance of chi-squared tests of coefficient restrictions. $H 1$ imposes the constraint that the coefficient on the growth of domestic credit is -1 . $H 2$ imposes the restrictions that the coefficients on UK and US domestic credit growth are equal to -1 and +1 respectively. $H 3$ restricts the coefficient on $\theta$ to be -1 , and $H 4$ restricts the coefficient on the growth of domestic credit to be -1 , and the coefficient on $\theta$ to be -1 . 


\section{Postscript}

Pegged exchange rate regimes based on gold at times worked well for some countries, during the classical gold standard period to 1914 for example. However, rates pegged against gold were implicated as a cause of the Great Depression in the 1930s, of prolonging the depression in the Gold Bloc countries (to 1936), and even in the 1890s of constraining economic growth in the USA by causing deflation. Pegged rate systems are also seen as vulnerable to the shock of warWWI certainly putting an end to the classical gold standard; and the foreshadowing of WWII quite possibly had a hand in ending the Gold Bloc.

Many economists were of the opinion that the gold standard imposed a too harsh financial discipline on domestic economies and that output and employment were sacrificed for external equilibrium. This provided motivation to devise, at Bretton Woods in 1944, a new managed international monetary system, one still linked to gold to secure price-stability but with a greater element of international management. The managed elements of the system came in provisions for adjustment of exchange rate parities and for supplementing international reserves through borrowing from a new international organization, the International Monetary Fund.

The system, however, evolved in a manner unforeseen by its designers. Little use was made of the provisions which permitted discretionary management. Parities for currencies were changed infrequently and the demand for additional international reserves was met not by extra borrowing facilities at the IMF, or, even by new gold, but by vastly increased dollar holdings. The flood of dollars which engulfed the world economy in the early-1970s - which could not be exchanged for gold from the US reserves because of the latter's inadequacy, led to mistrust in the dollar and to a series of crises which wrecked the system. From the turmoil there emerged a flexible exchange rate 
system, sometimes described as 'dirty' floating, and, perhaps somewhat surprisingly, not a lesser role for the dollar but rather the demonetization of gold. The latter event, reduced monetary discipline (see Table 1), and is associated with the unprecedented world inflation of the 1970s and 1980s. Nor has the experience with floating exchange rates been edifying. Nominal exchange rates move around so much that they are thought to distort real exchange rates and real economic activity ${ }^{13}$; future exchange rates are largely unpredictable; and the insulation property of floating rates has turned out to be chimerical.

\section{Dollar standard in an era of volatile exchange rate expectations}

McKinnon $(1982,1988)$ discusses the behavior of the dollar standard to cover the present system of floating exchange rates. The heyday of the dollar standard was during the 1950s and 1960s when it was approximately true that:-

a) the dollar was the only reserve currency and the rest of the world (ROW), not the USA, intervened in foreign exchange markets to stabilize exchange rates;

b) the rest of the world held its foreign exchange reserves as US Treasury securities rather than as Federal Reserve liabilities. (As we have seen this is true today of the dollar component of foreign exchange reserves). This gave (and gives) rise to passive sterilization of US balance of payments deficits on the US money base - base money 'lost' through a US payments deficit was (and still is) replaced by foreign central banks when they buy Treasury securities; and

c) the ROW was (and remains to some degree) unable effectively to sterilize the effect of capital inflows/outflows on its own money base.

Currency substitution out of the dollar raises base money in the ROW without reducing it in the US - the world's money base is thereby increased. The world's money base is reduced when currency substitution is into the dollar. The ROW's foreign exchange reserves and money supply decline

\footnotetext{
${ }^{13}$ For example, President Sarkozy of France in late-2007 repeated complained about the over-valution of the euro against the US dollar.
} 
while the currency inflow into the US is passively sterilized in the USA. In effect, the ROW's central banks and private sector swap ownership of US securities - which has no effect on the US money base - while the reduction in the ROW central bank's assets reduces the money base of the ROW.

McKinnon supposes, and there is some evidence for this, that at the aggregate level, the world's demand for money is a stable function of a few variables. The share of the dollar in this stable demand, however, is a negative function of the expected rate of depreciation of the dollar.

Assumptions b) and c) imply that control of world base money is entirely at the discretion of the Federal Reserve. Respectively, passive sterilization stabilizes America's money; and assumption c) amounts to the claim that the ROW has no control over its own base money. For example, if the ROW attempted to lower its money base by raising interest rates, capital inflow from the US would thwart the attempt.

Since only the USA's money base is independently controlled, McKinnon draws the startling conclusion that:-

$$
\mathrm{M}^{\mathrm{W}}=\mathrm{A} / \beta\left(\Delta \mathrm{s}^{\mathrm{e}}\right)
$$

where $\mathrm{M}^{\mathrm{W}}$ is the world money base; $\mathrm{A}$ is the domestic assets of the Federal Reserve: $\beta$ is the dollar's share of world base money, and $\beta$ depends inversely on the expected rate of depreciation of the dollar, $\Delta \mathrm{s}^{\mathrm{e}}$

In the 1960s, $\beta$ was close to unity, i. e., the dollar was virtually the only reserve currency (the sterling area was then on the way out), and $\Delta \mathrm{s}^{\mathrm{e}}$ changed little under the pegged exchanged rate regime. Thus, not only was $\beta$ close to unity, it was also stable around that value. America set the world's money base and changes in Federal Reserve assets had a predictable effect on it. 
However, in the last three decades $\beta$ has fallen sharply as the share of dollars in foreign exchange reserves has been reduced to about 55 percent in the early-1990s. That is, the world money base multiplier, $1 / \beta$ is larger today than in the $1960 \mathrm{~s}$. Moreover, expectations of dollar depreciation, $\Delta \mathrm{s}^{\mathrm{e}}$, have become highly volatile, which implies that not only is the base multiplier larger, it is also much more unstable.

\section{A currency board system: Argentina, 1991-2002}

Pertinent to the choice of currency board system - in which issue of domestic currency is rigidly tied to changes in foreign exchange holdings and, if there is an exchange rate fluctuation band, it is very narrow, is the asymmetry of shocks and especially the asymmetry of permanent shocks, between a pair of countries in a monetary union. Hallwood, Marsh and Scheibe (2005) find that permanent shocks to Argentina and the United States remained highly asymmetric even in the later years of the Argentine currency board system. Ultimately these shocks destroyed the case for a rigidly pegged exchange rate between Argentina and the United States. The problem is that the occurrence of asymmetric shocks requires real exchange rate flexibility if macroeconomic stability is to be maintained. This conclusion is entirely supportive of the prescient observation by Bayoumi and Eichengreen (1994) that in the Americas, including Argentina, "countries in this region would have to undertake very major adjustments in policy and performance in laying the groundwork for monetary union" (page 34-35). Unfortunately, price-deflation as a means of achieving this flexibility proved to be just too costly for Argentina. Economic and resulting political circumstances forced it to give up its currency board so allowing it to choose the other method of real exchange rate adjustment - through nominal exchange rate flexibility. Managed properly with disciplined monetary and fiscal policies, increased exchange rate flexibility may achieve the degree of real exchange rate flexibility appropriate for the Argentine economy.

Indeed, as a general rule, symmetry of economic shocks between countries is a necessary condition for a successful pegged exchange rate system to operate. This is especially true in democracies where governments do not have the time to ride out voter dissatisfaction with adverse economic conditions - inflation in countries with undervalued exchange rates and 
deflation in countries with overvalued exchange rates.

\section{Official dollarization in Latin American: would it work?}

The choice of monetary and exchange rate regimes in Latin America is a recurrent policy issue. In 2000 Ecuador and El Salvador officially dollarized, in 2002 Argentina abandoned its decade old currency board, and in 2003 it held discussions at the Ministerial level with Brazil to explore some sort of common currency arrangement. ${ }^{14}$ Hallwood, MacDonald and Scheibe (200) use the Blanchard Quah (1989) methodology on data from five Latin American countries Argentina, Chile, Brazil, Uruguay and Venezuela - to assess the case for monetary union either with the USA, through official dollarization, or between Latin American countries, through the adoption of a common currency arrangement. Shocks to real GDP deviations from trend are divided into permanent shocks (sometimes called supply-side shocks) and temporary shocks (sometimes called demand-side shocks). Low correlation between permanent shocks - e.g. one country is in recession while the other is in a boom, is taken to indicated that monetary union between the pair of countries is inadvisable - because a suitable exchange rate adjustment would help in restoring balance between the economies. The evidence in Table 4 rather strongly indicate low correlation of either temporary or permanent shocks between any of the five Latin American countries; or, between any one of them and the USA. On this evidence the conclusion has to be that Latin American monetary union with the USA is not a good option. The five Latin American countries concerned should maintain a non-pegged exchange rate with the US dollar.

14 "Brazil, Argentina consider forming a common currency", May $5^{\text {th }}, 2003$, Bloomberg.com. 


\section{Table 4: Correlations of permanent and temporary shocks}

Panel A Permanent Shocks

US (t) US (t-1) US (t-2) US (t-3) US (t-4) ${ }_{a}^{\text {Argentin }}$ Brazil Chile Uruguay

\begin{tabular}{lllllllllll}
\hline Argentina & 0.07 & 0.13 & 0.07 & 0.27 & 0.20 & 1.00 & & & \\
Brazil & -0.38 & 0.02 & -0.27 & 0.19 & 0.08 & 0.22 & 1.00 & & \\
Chile & -0.08 & 0.08 & -0.10 & -0.11 & 0.26 & 0.35 & 0.07 & 1.00 & \\
Uruguay & 0.10 & 0.33 & -0.08 & 0.16 & 0.06 & 0.38 & 0.17 & 0.22 & 1.00 \\
Venezuela & 0.16 & -0.18 & -0.07 & -0.14 & -0.06 & -0.05 & -0.28 & 0.32 & -0.20 \\
\end{tabular}

Panel B Temporary Shocks

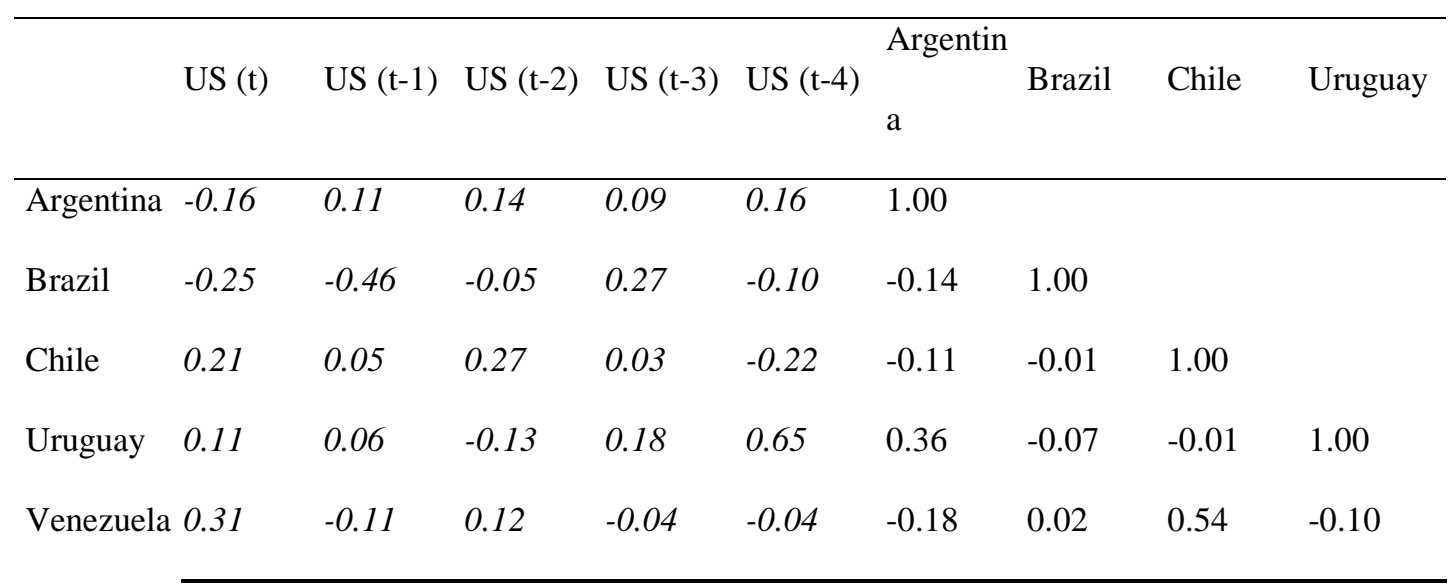

Note: The first column of panel A shows the contemporaneous correlation of the estimated permanent shocks of each country with those of the US. The next four columns show correlations of current country shocks with lagged US shocks. The final four columns show contemporaneous correlations with other Latin American nations' permanent shocks. Panel B repeats this for temporary shocks. 


\section{Conclusions}

Thus, a sifting of the contemporaneous financial evidence of exchange rate realignment expectations leads to the conclusion that the credibility of currency pegs has declined from one pegged regime to the next: in the historical order of classical gold standard, inter-war gold standard, Bretton Woods system, European Monetary system (not discussed here, but subjected to frequent currency realignments while it operated). And now there is New Bretton Woods system the stability of which is questionable largely because of the huge accumulation of dollar foreign exchange reserves in countries such as China and some oil exporters. Diversification out of dollars into another reserve currency, the euro, would affect the world money base.

Some possible reasons for deepening problems with pegged exchange rate systems are:

i) Declining resolve - as viewed by actors in financial markets - of governments to defend declared exchange rate pegs. i.e., the ability of governments to make a credible commitment has declined and the time inconsistency problem has increased, financial actors realize this and make 'one-way' speculative bets on exchange rate movements.

ii) Fiscal imbalances have become larger and more persistent, so exerting greater pressures in foreign exchange markets.

iii) Monetary policies have become more active.

iv) Increasing inflation persistence has increased.

v) Decreasing wage-price flexibility as reflected in the steepening of Phillips curves.

vi) Increasing volumes of short-term capital flows which make exchange rate pegs more difficult to defend. 
vii) Increased differential shocks between countries which are better coped with by floating exchange rates.

\section{References}

Alogoskoufis, G.S. and Smith, R. (1991), "The Phillips Curve, the Persistence of Inflation, and the Lucas Critique: Evidence from Exchange Rate Regimes", American Economic Review, 81 (5), 1254-75

Anthony, M. and MacDonald, R. (1998), "On the Mean Reverting Properties of Target Zone Exchange Rates: Some Evidence from the ERM", European Economic Review, 42, 14931523.

Anthony, M. and MacDonald, R. (1999), "The Width of the Exchange Rate Band and Exchange Rate Mean Reversion: Some Further ERM-based Results", International Journal of Money and Finance, 18, 411-28.

Bayoumi, T. and B. Eichengreen (1994). "Macroeconomic adjustment under Bretton Woods and the post-Bretton-Woods float: an impulse-response analysis." Economic Journal 104(425 (July)): 813-827.

Bertola, G. and Caballero, R.J. (1992), "Target Zones and Realignment”, American Economic Review, 82, 520-36.

Bertola, G and Svensson, L. (1993), "Stochastic Devaluation Risk and the Empirical Fit of Target Zone Models", Review of Economic Studies, 60, 689-712.

Blanchard, O.J. and D. Quah, 1989, The Dynamic Effect of Aggregate Demand and Supply Disturbances, American Economic Review, 79, 655-673.

Bloomfield, A. I.(1959), Monetary Policy Under the International Gold Standard, Reprinted Arno Press, NY, 1978.

Bordo, M. D. and Kydland, F.E. (1992), "The Gold Standard as a Rule”, Federal Reserve Bank of Cleveland, Working Paper 92-05

Brown, W.A. (1940), The International Gold Standard Reinterpreted 1914-1934, NBER.

Cassel, G. (1935), Foreign Investments, Lectures of the Harris Foundation, Chicago University Press.

Clark, T.A. (1984), "Violations of the Gold Points", Journal of Political Economy, 92 (5), 791-823.

Dooley, M.P., Folkerts-Landau, D. and Garber, P. (2003), "An Essay on the Revived Bretton Woods System", NBER working paper 9971

Eichengreen, B. (1992), Golden Fetters: The Gold Standard and the Great Depression, Oxford University Press, Oxford and NY.

Eichengreen, B. and Flandreau, (1996), "Blocks, Zones and Bands: International Monetary History in the Light of Recent Theoretical Developments", Scottish Journal of Political Economy, 43 (4), 398-418

Eichengreen, B., Watson, M.W., and Grossman, R.S. (1985), "Bank Rate Policy Under the InterWar Gold Standard", Economic Journal, 95 725-45.

Einzig, P. (1937), World Finance, MacMillan, New York

Friedman, M. and Schwartz, A. (1963), A Monetary History of the United States, 1867-1960, Princeton University Press, NJ.

Gallarotti, G. M. (1995), The Anatomy of an International Monetary Regime: The Classical Gold Standard, 1880-1914, Oxford University Press, Oxford and NY. 
Giovannini, A. (1993), "Bretton Woods and its Precursors: Rules Versus Discretion in the History of the International Monetary System", in M. Bordo and B. Eichengreen, A Retrospective on the Bretton Woods System, Chicago University Press, Chicago, 109-153.

Girton, L. and Roper, D. (1977), "A Monetary Model of Exchange Market Pressure Applied to the Post-War Canadian Experience”, American Economic Review, 67, 537-48.

Goodhart, C. (1972), The Business of Banking 1891-1914, Gower, Aldershot.

Hallwood, P., MacDonald, R. and Marsh, I. (2007), "Did Impeding War in Europe Help Destroy the Gold Bloc in 1936? An Internal Inconsistency Hypothesis" Working papers 2007-23, University of Connecticut, Department of Economics.

Hallwood, P., MacDonald, R. and Marsh, I. (1999),

Hallwood, P., MacDonald, R. and Marsh, I. (1996), "Credibility and Fundamentals: Were the Classical and Inter-War Gold Standards Well-Behaved Target Zones?" In Modern Perspectives on the Gold Standard, (edited by T. Bayoumi, B. Eichengreen, and M.P. Taylor), Cambridge University Press, Cambridge, England.

Hallwood, P. MacDonald, R. and Marsh, I (2000a), "An Assessment of the Causes of the Abandonment of the Gold Standard by the USA in 1933", Southern Economic Journal, 67 (2), October, 448-459.

Hallwood, P., MacDonald, R. and Marsh, I. (2000b) "Realignment Expectations and the US Dollar: Was there a Peso Problem?", Journal of Monetary Economics, 46, 605-620.

Hallwood, P. MacDonald, R. and Marsh, I. (1997), "Crash! Expectational Aspects of the UK's and the USA's Departures from the Inter-War Gold Standard", Explorations in Economic History, 34, 174-194.

Hallwood, P. and Marsh, I. (2004), "Exchange Market Pressure on the Pound-Dollar Exchange Rate, 1925-1931", North American Journal of Economics and Finance. Vol 15 (2).

Hallwood, P. Marsh, I. and Scheibe, J. (2005), "Economic Shocks and Choice of Currency Area: the Case of Argentina, 1991-2002". In Capital Flows and Exchange Rates, edited by R. Driver, C. Thoenissen and P. Sinclair, Routledge.

Hallwood, P., Marsh, I and Schiebe J. (2006), “An Assessment of the Case for Monetary Union or Official Dollarization in Five Latin American Countries", (with Ian W. Marsh and Jorg Scheibe), Emerging Market Review, 7 (1), March.

Hogg, R.L. (1987), Chapter 9 in R.T. Griffiths, The Netherlands and the Gold Standard, 1931 36, Neha, Amsterdam

Kindleberger, C. P. (1986), The World in Depression: 1929-1939, University of California Press, Berkeley.

Kissinger, H. (1994), Diplomacy, Simon and Schuster, New York

Krugman, P. (1988), "Target Zones and Exchange Rate Dynamics”, NBER, Working Paper, 2481.

Kohlscheen, E_W, (2000), "Estimating Exchange Market Pressure and Intervention Activity", Working Paper Series, Central Bank of Brazil, November.

Kydland, F.E. and Prescott, E.C. (1977), "Rules Rather than Discretion: the Inconsistency of Optimal Plans", Journal of Political Economy, 77, 473-91

Lindert, P. (1969), Key Currencies and Gold: 1900-1913, Princeton Studies in International Finance, No. 24.

McCloskey, D.N. and Zecher, J.R. (1976), "How the Gold Standard Worked, 1880-1913”, in J.A. Frenkel and H.G. Johnson, The Monetary Approach to the Balance of Payments, Toronto University Press, Toronto, 357-85 
McKinnon, R. I. (1982), "Currency Substitution and Instability in the World Dollar Standard", American Economic Review, 72 (3), 320-33

McKinnon, R. I. (1988), "Monetary and Exchange Rate Policies for International Financial Stability: A Proposal", Journal of Economic Perspectives. 2, 83-103

Miller, M. and Weller, P. (1991), "Currency Bands, Target Zones and Price Flexibility”, IMF Staff Papers, 38, 184-215

Mizrach, B. (1995), "Target Zone Models with Stochastic Realignments: An Econometric Evaluation”, Journal of International Money and Finance, 14 (5) , 641-57.

Moggridge, (1969),

Morgan-Webb, C. (1934), The Rise and Fall of the Gold Standard, MacMillan, NY.

Mundaca, G. (2004), "Modelling Probabilities of Devaluations", Economica, 71, 13-37.

Officer, L (1993), "Gold Point Arbitrage and Uncovered Interest Arbitrage Under the 1925-31 Dollar-Sterling Gold Standard”, Explorations in Economic History, 30 (1), 98-127.

Schwartz, A. (1987), Money in Historical Perspective, University of Chicago Press, Chicago.

Svensson, L. (1991), “The Simplest Test of Target Zone Credibility. IMF Staff Papers, 38, 655-65.

Svensson, L. (1992), "An Interpretation of Recent Research on Exchange Rate Target Zones", Journal of Economic Perspectives, 6 (4), 119-44.

Temin, P. (1989), The Lessons from the Great Depression, MIT Press, Cambridge, MA.

Tullio, G. and Walters, J. (1996), "Was London the Conductor of the International Orchestra or Just the Triangle Player? An Empirical Analysis of Asymmetries in Interest Rate Behaviour During the Classical Gold Standard, 1876-1914", Scottish Journal of Political Economy, 43 (3), 419-43.

Weymark, D.N. (1998), “A General Approach to Measuring Exchange Market Pressure” Oxford Economic Papers, 50, 106-121.

Weymark, D. N. (1997) "Measuring the Degree of Market Intervention in a Small Open Economy," Journal of International Money and Finance 16: 55-79. 